\title{
Evaluating ion exchange resin efficiency and oxidative capacity for the separation of uranium (IV) and uranium(VI)
}

\author{
Deborah L Stoliker ${ }^{\text {** }}$, Nazila Kaviani ${ }^{1}$, Douglas B Kent ${ }^{1}$ and James A Davis ${ }^{2}$
}

\begin{abstract}
Background: Previously described methods to separate dissolved U(IV) from dissolved U(VI) under acidic anoxic conditions prior to laboratory analysis were ineffective with materials currently available commercially. Three strong anion exchange resins were examined for their efficiency in separating, recovering, and preserving both redox states during separation.

Results: Under oxic conditions, recovery of $U(V)$ from three exchange resins (Bio-Rad $A G^{\circledR}$ 1x8 Poly-Prep ${ }^{\circledR}$ prefilled columns, Bio-Rad $A G^{\circledR} 1 \times 8$ powder, and Dowe ${ }^{\circledR} 1 \times 8$ powder) ranged from $72 \%$ to $100 \%$ depending on the dosed mass, eluent volume, and resin selected. Dowex ${ }^{\circledR} 1 \times 8$ resin was the only resin found to provide $100 \%$ recovery of $U$ (VI) with fewer than 5 bed volumes of eluent. Under anoxic conditions, all three resins oxidized U(IV) in aqueous solutions with relatively low $\mathrm{U}(\mathrm{IV})$ concentrations $\left(<3 \times 10^{-6} \mathrm{M}\right)$. Resin-induced oxidation was observed visually using a leuco dye, safranin-o. Oxidants associated with the resin were irreversibly reduced by the addition of Ti(III). After anoxic resin pre-treatment, a series of $\mathrm{U}(\mathrm{IV}) / \mathrm{U}(\mathrm{VI})$ mixtures at micro-molar levels were prepared and separated using the Dowex ${ }^{\circledR} 1 \times 8$ resin with $100 \%$ recovery of both $\mathrm{U}(\mathrm{IV})$ and $\mathrm{U}(\mathrm{VI})$ with no resin-induced changes in oxidation state.

Conclusions: Currently available anion exchange resins with apparently identical physical properties were found to have significantly different recoveries for hexavalent uranium at micro-molar concentrations. A novel qualitative technique was developed to visually assess oxidative capacities of anion exchange resins under acidic anoxic conditions. A protocol was developed for pre-treatment and use of currently available anion exchange resins to achieve quantitative separation of $U(I V)$ and $U(V I)$ in aqueous solutions with low $U(I V)$ concentrations. This method can be applied to future work to quantitatively assess dissolved $U(I V)$ and $U(V I)$ concentrations in both laboratory and field samples.
\end{abstract}

Keywords: Anion exchange, Resin separation, Uranium(IV), Uranium(VI), Uranium speciation

\section{Background}

Uranium exists naturally in the environment within host rocks, soils, groundwaters, and surface waters. Mobilization of naturally occurring uranium can lead to groundwater concentrations in excess of the drinking water standard of $1.3 \times 10^{-7} \mathrm{M}$ or $30 \mathrm{ppb}[1,2]$. More commonly, mining and processing of uranium ore, as well as nuclear weapons development, has resulted in the development of persistent groundwater plumes with elevated uranium concentrations at a number of sites around the world [3-5]. Under oxic

\footnotetext{
* Correspondence: dlstoliker@usgs.gov

'U.S. Geological Survey, 345 Middlefield Rd, Menlo Park, CA 94025, USA

Full list of author information is available at the end of the article
}

conditions uranium is present as hexavalent $\mathrm{U}(\mathrm{VI})$, while under sub-oxic and reducing conditions tetravalent U(IV) is the predominant form [6]. Remediation strategies for many uranium contaminated sites are currently focused on both biotic and abiotic reduction of the readily mobile $\mathrm{U}(\mathrm{VI})$ to $\mathrm{U}(\mathrm{IV})$ as uraninite, which has a very low solubility at near-neutral and alkaline $\mathrm{pH}$ values [7-13].

Recent work has suggested the presence of U(IV) in forms that are potentially more labile than uraninite in uranium-contaminated aquifer and vadose-zone sediments, often attributed to an association with organic matter [14-22]. These non-uraninite-U(IV) phases can be solubilized under aerobic and anaerobic conditions $[19,21]$ however detection of dissolved U(IV) with

\section{() Biomed Central}


laboratory-based (non-synchrotron) instrumentation is not possible due to the rapid oxidation of $U(I V)$ to $U$ (VI) under conditions typically required for instrumental determinations of low concentrations of uranium. Kinetic phosphorescence analysis (KPA) offers a means to detect only dissolved $\mathrm{U}(\mathrm{VI})$ due to the luminescent nature of hexavalent uranium and non-luminescence of other valence states $[23,24]$. However, oxidation of U(IV) may occur during sample exposure to atmospheric conditions or acidification with nitric acid, commonly required for analysis.

For this reason, separation of dissolved U(IV) and U(VI) under anaerobic conditions prior to contact with nitric acid and instrumental analysis, is desired. Strongly basic anion exchange resins have been used previously to separate $U(I V)$ and $U(V I)$ [7,25-28]. These resins are composed of quaternary trialkylammonium functional groups attached to a styrene divinylbenzene polymer lattice $[29,30]$. In hydrochloric acid solutions of concentrations greater than $3.5 \mathrm{M}, \mathrm{U}(\mathrm{VI})$ forms anionic chloro-complexes which adsorb extensively to the resin. In contrast, U(IV) remains as cationic species which adsorb minimally below $\mathrm{HCl}$ concentrations of $5.5 \mathrm{M}[25,27,28]$. Separation of the two oxidation states can be achieved by introducing a $4 \mathrm{M}$ $\mathrm{HCl}$ solution containing $\mathrm{U}(\mathrm{IV})$ and/or $\mathrm{U}(\mathrm{VI})$ to a column packed with anion exchange resin, flushing with $4 \mathrm{M} \mathrm{HCl}$, and collecting the eluate. Under these conditions, only $\mathrm{U}$ (IV) will pass through the resin bed. Uranium(VI) is then eluted with $0.1 \mathrm{M} \mathrm{HCl}$, which allows the U(VI)-chloro complexes to dissociate. Analysis of the separate fractions can then be carried out via KPA after sample preparation during which U(IV) fractions will be oxidized. In order to achieve uranium mass balance and quantify dissolved concentrations, both $\mathrm{U}(\mathrm{IV})$ and $\mathrm{U}(\mathrm{VI})$ recoveries need to be reproducible and complete (i.e. 100\%). In addition, any functional groups or constituents associated with the resin must not oxidize U(IV) nor reduce U(VI). Both of these issues, poor recovery and resin-induced $\mathrm{U}(\mathrm{IV})$ oxidation, were observed by the authors when first attempting to utilize currently available commercial anion exchange resins for the separation of $U(I V)$ and $U(V I)$ even in simple, aqueous hydrochloric acid solutions. Many recent studies have focused on the use of anion-exchange resins to remove $\mathrm{U}(\mathrm{VI})$ from natural systems under ambient conditions [30-33]. However, to our knowledge, the issue of resin-induced oxidation of U(IV) under the acidic conditions necessary for U(IV)/U(VI) separation has not been reported. In this paper, we evaluate the use of anion exchange resins currently available commercially for $\mathrm{U}$ (IV)/U(VI) separation, present novel techniques to provide immediate visual confirmation of whether anion exchange resins possess oxidative capacity, and develop a protocol that can be used to achieve quantitative separation of $U$ (IV) and U(VI) from anoxic hydrochloric acid solutions with micro-molar uranium concentrations. Complications associated with potential oxidation of U(IV) by constituents such as $\mathrm{Fe}(\mathrm{III})$ present in environmental samples are eliminated by working in simple, aqueous hydrochloric acid solutions [6].

\section{Methods}

\section{Recovery of $\mathrm{U}(\mathrm{VI})$ under oxic conditions}

Before evaluating $\mathrm{U}(\mathrm{IV}) / \mathrm{U}(\mathrm{VI})$ separation and recovery, the efficiency of $\mathrm{U}(\mathrm{VI})$ recovery using several different resins was examined under oxic conditions. Based on cost, descriptions in published studies, and previous experience in our laboratory, three strong anion exchange resins in the chloride form (100-200 mesh with $1.2 \mathrm{meq}$ $/ \mathrm{mL}$ exchange capacity) were selected for testing: BioRad $A G^{\circledR} 1 \times 8$ Poly-Prep ${ }^{\circledR}$ prefilled columns, Bio-Rad $\mathrm{AG}^{\circledR} 1 \times 8$ powder, and Dowex ${ }^{\circledR} 1 \times 8$ powder. The use of trade, product, or firm names herein is for descriptive purposes only and does not imply endorsement by the U.S. Government. Resins were packed and evaluated in various columns, including both the Bio-Rad Poly-Prep ${ }^{\circledR}$ polypropylene columns $\left(0.8 \mathrm{~cm}\right.$ ID with a $\operatorname{Kynar}^{\circledR} 20 \mu \mathrm{m}$ frit resin bed support and an attached luer-slip, 2-way stop-cock) and Thermo Scientific ${ }^{\circledR}$ Pierce $^{\circledR}$ polystyrene columns $(0.7 \mathrm{~cm}$ ID with two $30 \mu \mathrm{m}$ polyethylene discs situated above and below the resin bed) (Figure 1). Bed volumes calculated for packed columns were 1.4-2 mL (corresponding to exchange capacities of 1.7-2.4 meq). Powder resins were pre-washed in batch prior to column packing by suspension in $0.1 \mathrm{M} \mathrm{HCl}$, settling, and decanting the supernatant. This step was performed with $\sim 2-5$ g of resin mixed with $\sim 20 \mathrm{~mL}$ of acid four times. A final addition of $20 \mathrm{~mL}$ of $0.1 \mathrm{M} \mathrm{HCl}$ was used to slurry pack the column. Resin columns were then flushed with at least 10 bed volumes of $4 \mathrm{M} \mathrm{HCl}$ prior to addition of uranium-containing solutions (Table 1). Pre-packed resins were pre-washed by draining the packing solution (deionized water), flushing with 3 bed volumes of deionized water with a resistivity of $>18 \mathrm{M} \Omega \mathrm{cm}$ followed by $0.1 \mathrm{M} \mathrm{HCl}$, and flushing with at least 10 bed volumes of $4 \mathrm{M} \mathrm{HCl}$. All hydrochloric acid solutions were prepared from dilution of trace-metal grade concentrated acid (Thermo Fisher Scientific, Waltham, MA). Oxic uranium secondary stock solutions $\left(2 \times 10^{-6} \mathrm{M}, 8 \times 10^{-6} \mathrm{M}\right.$, and $2 \times 10^{-5} \mathrm{M}$ ) were prepared by dilution of a primary stock in $4 \mathrm{M} \mathrm{HCl}$. The primary uranium stock solution $\left(1 \times 10^{-2} \mathrm{M}\right)$ was prepared by dissolution of $\mathrm{UO}_{3}$ in hydrochloric acid. Secondary uranium stock solutions $(1 \mathrm{~mL})$ were added to the resin-packed columns, eluted with multiple bed volumes (3-6) of $4 \mathrm{M} \mathrm{HCl}$ collected as separate fractions of $\sim 2 \mathrm{~mL}$, and then eluted with multiple bed volumes (6-10) of $0.1 \mathrm{M} \mathrm{HCl}$ collected as separate fractions of $\sim 2 \mathrm{~mL}$. 

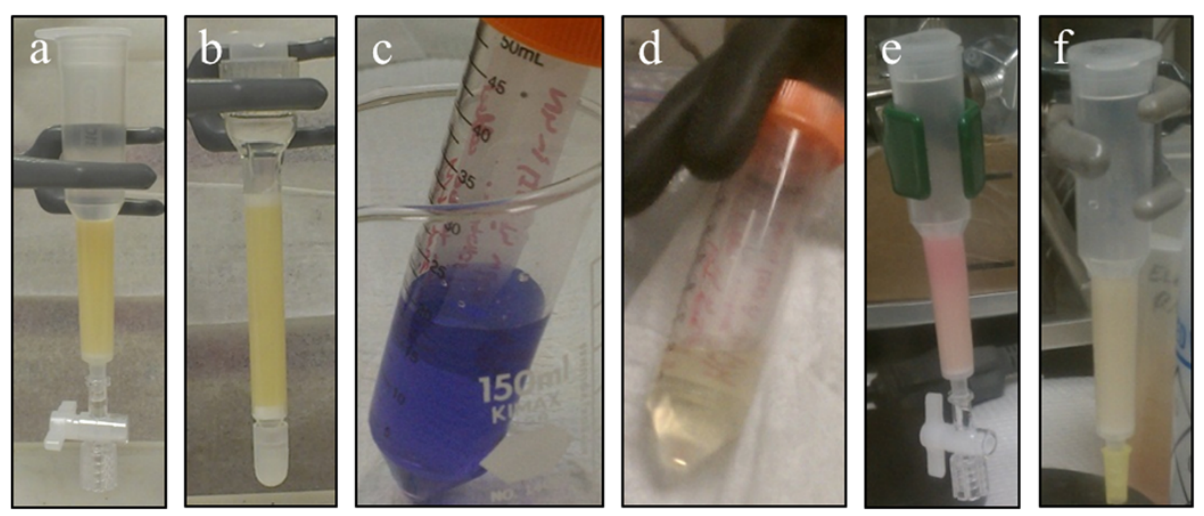

Figure 1 Use of safranin-o leuco dye as a visual oxidation indicator. a) Bio-Rad ${ }^{\circledR}$ AG1x8 resin in Poly-prep column including a stop-cock valve to control flow without indicator dye showing original color of the resin; b) Dowex ${ }^{\circledR} 1 \times 8$ resin in Pierce polystyrene column including top and bottom frits to control flow without indicator dye showing original color of the resin; c) Solution of safranin-o in the oxidized form (1 drop of $1 \%$ solution in $4 \mathrm{M} \mathrm{HCl}$ ); d) Anoxic safranin-o (colorless, reduced form) in $4 \mathrm{~N} \mathrm{HCl}$ after reduction with Ti(III); e) Example of anoxic resin (no pretreatment) after addition of reduced safranin-o solution with visible oxidation (pink color on resin); $\mathbf{f}$ ) Anoxic resin after pre-treatment with Ti(III) and addition of reduced safranin-o solution (no color change observed).

A split of each fraction was dried in a glass scintillation vial on a hot plate and converted to a nitrate salt by repeated drying after addition of $1 \mathrm{~mL}$ of concentrated nitric acid (Thermo Fisher Scientific, Waltham, MA) and $0.2 \mathrm{~mL}$ of $30 \%$ hydrogen peroxide (Thermo Fisher Scientific, Waltham, MA). These steps are necessary to avoid KPA interferences caused by $\mathrm{Cl}^{-}$and dissolved organic matter. Fractions for column separations and all other samples analyzed to determine uranium concentrations were treated similarly.
To determine dissolved U(VI) concentrations, the dried nitrate salts were then reconstituted in $0.15 \mathrm{M}$ nitric acid and analyzed on a Chemchek KPA-11 (Chemchek, Richland, WA). Briefly, the diluted uranium solution was mixed with a proprietary complexing agent that enhances its photoluminescence. The sample was excited by a pulsed laser and the phosphorescent intensity vs. time recorded [24]. For each analysis, 1000 laser pulses were averaged and sample lifetimes ranged between 280 and $300 \mu \mathrm{s}$. The analytical range for quantifying uranium

Table 1 Adopted method for the anoxic separation of $U(I V) / U(V I)$ at micro-molar concentrations

\begin{tabular}{|c|c|}
\hline Step & Protocol (in anoxic glovebag with anoxic solutions) \\
\hline 1 & $\begin{array}{l}\text { Wash } \sim 2-5 \mathrm{~g} \text { of Dowex }{ }^{\circledR} 1 \times 8 \text { resin }(100-200 \text { mesh, chloride form) with } \\
\sim 20 \mathrm{~mL} 0.1 \mathrm{M} \mathrm{HCl} \text {, repeat } 4 \mathrm{x}\end{array}$ \\
\hline 2 & $\begin{array}{l}\text { Use final rinse from Step } 1 \text { to slurry-pack a suitable column (such as a } \\
\text { Thermo Scientific }{ }^{\circledR} \text { Pierce polystyrene column, } 0.7 \mathrm{~cm} \text { ID with top and } \\
\text { bottom frits) to } 1.5-2 \mathrm{~mL} \text { bed volume }\end{array}$ \\
\hline 3 & Flush resin-packed column with $4 \mathrm{M} \mathrm{HCl}$ ( 10 bed volumes) \\
\hline
\end{tabular}

$4 \quad$ Add two successive flushes of $1 \times 10^{-2} \mathrm{M} \mathrm{Ti}(\mathrm{III})$ (2 bed volumes each) in 4 $\mathrm{M} \mathrm{HCl}$ and, using end caps, seal in a final 1.5-2 bed volumes of Ti(III) and allow the packed resin column to soak for 3 or more days

5 Drain the resin column and flush with at least 10 bed volumes of $4 \mathrm{M}$ $\mathrm{HCl}$

6 Add uranium-containing solution in $4 \mathrm{M} \mathrm{HCl}(1 \mathrm{~mL})$. Elute column with a total of 9 bed volumes of $4 \mathrm{M} \mathrm{HCl}$ and collect fraction(s)

7 Elute column with a total of 9 bed volumes of $0.1 \mathrm{M} \mathrm{HCl}$ and collect fraction(s)

$8 \quad$ Flush column with a total of 7 bed volumes of $0.1 \mathrm{M} \mathrm{HCl}$

9 Flush column with a total of 7 bed volumes of $4 \mathrm{M} \mathrm{HCl}$

\section{Purpose/Importance}

Pre-wash to remove any residual material from resin production that can interfere with uranium analysis via KPA

Use a bed-height to column diameter ratio $>3$. In this study, bedheight to column diameter ratios between 5 and 7 were used with success

Pre-flush to ensure resin column is completely saturated with $4 \mathrm{M}$ $\mathrm{HCl}$

Pre-treat resin to reduce oxidants associated with the resin that cause oxidation of $\mathrm{U}(\mathrm{IV})$

To flush out residual Ti(III) prior to sample addition

To collect $U(\mathrm{IV})$ fractions, which pass through the resin at $4 \mathrm{M} \mathrm{HCl}$

To collect $\mathrm{U}(\mathrm{VI})$ fractions, which adsorb to resin at $4 \mathrm{M} \mathrm{HCl}$ but are eluted at $0.1 \mathrm{M} \mathrm{HCl}$

Post-flush to ensure all $U(V I)$ is flushed away and clean resin for future use

Post-flush to ensure all U(IV) is flushed away and resin column is in $4 \mathrm{M} \mathrm{HCl}$ state for future use 
concentrations was $1 \times 10^{-9}$ to $1 \times 10^{-6} \mathrm{M}$ with standard deviations of $3 \%$ based on repeated determinations of quality control standards measured over the time period during which experiments were conducted.

\section{Recovery of $\mathrm{U}(\mathrm{IV})$ and $\mathrm{U}(\mathrm{VI})$ under anoxic conditions}

All anoxic solutions were prepared in an anaerobic chamber (Coy Lab Products, Grass Lake, MI) with an atmosphere of $2-5 \%$ hydrogen balanced with nitrogen. Two fan boxes within the glovebag cycled the atmosphere through desiccant filled palladium Stak-Paks to control oxygen and humidity. Solutions were sparged using gas dispersion tubes with the hydrogen-nitrogen gas mix for several hours (depending on the volume of solution) and checked for dissolved oxygen colorimetrically with a CHEMetrics (Midland, VA) vacu-vial filled with Rhodazine $\mathrm{D}^{\mathrm{TM}}$, with an minimum detection limit of $1.6 \times 10^{-6} \mathrm{M}$. All laboratory supplies (e.g. pipette tips, sample vials, resin, resin columns, etc.) were equilibrated in the glovebag for a minimum of 24 hours prior to use. U(IV) secondary stock solutions were prepared by adding $10^{-3} \mathrm{M}$ or $10^{-2} \mathrm{M} \mathrm{Ti}(\mathrm{III})$ in $4 \mathrm{M} \mathrm{HCl}$ to anoxic U(VI) secondary stock solutions [27]. To prevent an excess of reactive $\mathrm{Ti}(\mathrm{III})$ in solution, sub-stoichiometric amounts of $\mathrm{Ti}(\mathrm{III})$ were added to achieve solutions $<100 \% \mathrm{U}(\mathrm{IV})$ (i.e. partly U(IV) and partly U(VI)). Anoxic Ti(III) solution was obtained from Thermo Fisher Scientific as 20\% $\mathrm{TiCl}_{3}$ in $2 \mathrm{M} \mathrm{HCl}$ purged with $\mathrm{N}_{2}$. Neither $\mathrm{Ti}(\mathrm{III})$ nor the resulting oxidized form, $\mathrm{Ti}(\mathrm{IV})$ produced by reaction with $\mathrm{U}(\mathrm{VI})$, sorb to the anion exchange resin in the presence of $4 \mathrm{M} \mathrm{HCl}$ or $0.1 \mathrm{M} \mathrm{HCl}$ [26]. Resin pre-washing and column packing were carried out in the same manner described for oxic recovery checks inside the glovebag with anoxic solutions. Further treatment steps required for anoxic separation are detailed in the results section.

\section{Results and discussion}

Recovery of $\mathrm{U}(\mathrm{VI})$ under oxic conditions

Bio-Rad $\mathrm{AG}^{\circledR} 1 \times 8$ Poly-Prep ${ }^{\circledR}$ prefilled columns were originally selected for $\mathrm{U}(\mathrm{IV}) / \mathrm{U}(\mathrm{VI})$ separation as this resin has been used previously for this task [7,27] and arrives pre-packed in a column ready for use. A two-way stop-cock valve was added to the column to prevent pore fluid from draining completely between eluent additions (Figure 1a). Recovery of U(VI) under oxic conditions was tested for this resin using $2.1 \times 10^{-6} \mathrm{M}$, and $2.2 \times 10^{-5} \mathrm{M}$ uranium solutions in $4 \mathrm{M} \mathrm{HCl}$. After preparing the resin columns, which included pre-washing, $1 \mathrm{~mL}$ of uranium solution was added followed by a minimum of 5 bed volumes $(10 \mathrm{~mL})$ of $4 \mathrm{M} \mathrm{HCl}$ eluent with measured flow rates of $\sim 0.45 \mathrm{~mL} / \mathrm{min}$. No uranium could be detected in any of the $4 \mathrm{M} \mathrm{HCl}$ fractions confirming strong adsorption of $\mathrm{U}(\mathrm{VI})$ to the resin
(Figure 2a). Subsequent elution with $0.1 \mathrm{M} \mathrm{HCl}$ resulted in slow recovery of $\mathrm{U}(\mathrm{VI})$ (Figure 2). Recovery of U(VI) ranged from $72 \%$ for a $2.1 \times 10^{-6} \mathrm{M}$ uranium solution to $86 \%$ for a $2.2 \times 10^{-5} \mathrm{M}$ solution after 9 bed volumes of $0.1 \mathrm{M} \mathrm{HCl}$ were passed through the column (Table 2). The slow, incomplete, recovery of U(VI) from these prepacked columns precluded their use in $\mathrm{U}(\mathrm{IV}) / \mathrm{U}(\mathrm{VI})$ systems, where quantification requires $100 \%$ recovery with reasonable volumes of eluent. New Poly-Prep ${ }^{\circledR}$ columns
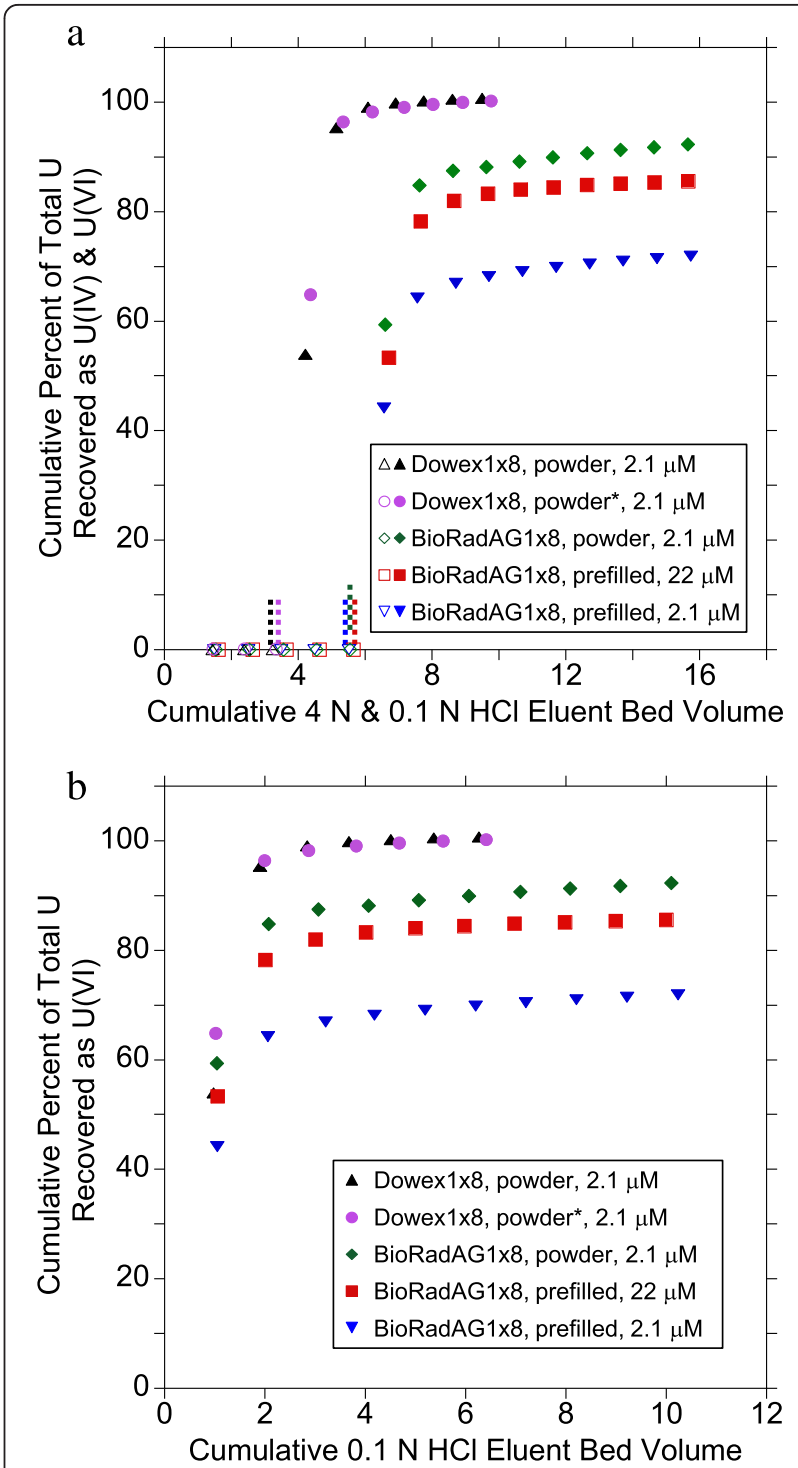

Figure 2 Recovery of $\mathrm{U}(\mathrm{VI})$ from various resins under oxic conditions. Resin separation of oxic U(VI) solutions using Bio-Rad ${ }^{\circledR}$ AG1x8 prefilled Poly-prep columns, Bio-Rad ${ }^{\circledR}$ AG1x8 powder packed in the Poly-prep columns and Dowex ${ }^{\circledR} 1 \times 8$ powder packed in the Poly-prep and Pierce polystyrene $\left(^{*}\right)$ columns showing a) cumulative recovery of total uranium for both $4 \mathrm{M} \mathrm{HCl}$ (open symbols, U(IV)) and $0.1 \mathrm{M} \mathrm{HCl}$ (closed symbols, U(VI)) column elution with dashed lines indicating where the eluent composition was changed for each system and b) cumulative recovery of total uranium as $U(V I)$ from only $0.1 \mathrm{M} \mathrm{HCl}(\mathrm{U}(\mathrm{VI}))$ elutions. 
Table 2 Summary of selected resin separation tests including treatment steps and outcome

\begin{tabular}{|c|c|c|c|c|c|c|c|c|c|}
\hline Resin & Column Type & $\begin{array}{l}\text { Oxic or anoxic } \\
\text { conditions }\end{array}$ & $\begin{array}{l}\mathrm{Ti}(\mathrm{III}) \\
\text { treatment }\end{array}$ & $\begin{array}{l}\text { Initial }\left[U_{\text {tot }}\right] \\
(\mu \mathrm{M})^{\mathrm{a}}\end{array}$ & $\begin{array}{l}U_{\text {tot }} \text { Recovered } \\
(\%)^{\mathrm{a}}\end{array}$ & $\begin{array}{l}\text { Initial U(IV) } \\
(\%)\end{array}$ & $\begin{array}{l}\text { Initial U(VI) } \\
\text { (\%) }\end{array}$ & $\begin{array}{l}\text { Recovered as U(IV) } \\
(\%)^{b}\end{array}$ & $\begin{array}{l}\text { Recovered as } \mathrm{U}(\mathrm{VI}) \\
(\%)^{\mathbf{b}}\end{array}$ \\
\hline $\begin{array}{l}\text { Bio-Rad AG1×8 } \\
\text { prefilled }\end{array}$ & $\begin{array}{l}\text { Bio-Rad Poly- } \\
\text { prep }\end{array}$ & Oxic & No & 2.1 & 72 & 0 & 100 & 0 & 100 \\
\hline $\begin{array}{l}\text { Bio-Rad AG1×8 } \\
\text { prefilled }\end{array}$ & $\begin{array}{l}\text { Bio-Rad Poly- } \\
\text { prep }\end{array}$ & Oxic & No & 22.2 & 86 & 0 & 100 & 0 & 100 \\
\hline $\begin{array}{l}\text { Bio-Rad AG1x8 } \\
\text { powder }\end{array}$ & $\begin{array}{l}\text { Bio-Rad Poly- } \\
\text { prep }\end{array}$ & Oxic & No & 2.1 & 92 & 0 & 100 & 0 & 100 \\
\hline Dowex $1 \times 8$ powder & $\begin{array}{l}\text { Bio-Rad Poly- } \\
\text { prep }\end{array}$ & Oxic & No & 2.1 & 100 & 0 & 100 & 0 & 100 \\
\hline Dowex 1x8 powder & $\begin{array}{c}\text { Pierce } \\
\text { polystyrene }\end{array}$ & Oxic & No & 2.1 & 100 & 0 & 100 & 0 & 100 \\
\hline $\begin{array}{l}\text { Bio-Rad AG1×8 } \\
\text { prefilled }\end{array}$ & $\begin{array}{l}\text { Bio-Rad Poly- } \\
\text { prep }\end{array}$ & Anoxic & No & 2.1 & 81 & 36 & 64 & 0 & 100 \\
\hline Dowex $1 \times 8$ powder & $\begin{array}{c}\text { Pierce } \\
\text { polystyrene }\end{array}$ & Anoxic & No & 8.7 & 100 & 98 & 2 & 86 & 14 \\
\hline Dowex $1 \times 8$ powder & $\begin{array}{c}\text { Pierce } \\
\text { polystyrene }\end{array}$ & Anoxic & Yes & 8.7 & 100 & 98 & 2 & 98 & 2 \\
\hline Dowex $1 \times 8$ powder & $\begin{array}{c}\text { Pierce } \\
\text { polystyrene }\end{array}$ & Anoxic & Yes & 1.8 & 100 & 0 & 100 & 0 & 100 \\
\hline Dowex 1x8 powder & $\begin{array}{c}\text { Pierce } \\
\text { polystyrene }\end{array}$ & Anoxic & Yes & 2.8 & 100 & 100 & 0 & 100 & 0 \\
\hline Dowex $1 \times 8$ powder & $\begin{array}{c}\text { Pierce } \\
\text { polystyrene }\end{array}$ & Anoxic & Yes & 2.1 & 100 & 10 & 90 & 11 & 89 \\
\hline Dowex $1 \times 8$ powder & $\begin{array}{c}\text { Pierce } \\
\text { polystyrene }\end{array}$ & Anoxic & Yes & 1.8 & 100 & 48 & 52 & 47 & 53 \\
\hline
\end{tabular}

a. $1 \mathrm{~mL}$ of uranium solution added to resin, uncertainty in recovered $\mathrm{U}_{\text {tot }}$ was $3 \%$.

b. Uncertainty in speciation recovery was $1 \%$. 
were emptied, rinsed, re-packed with a pre-washed slurry of Bio-Rad $\mathrm{AG}^{\circledR} 1 \times 8$ in powder form, $1 \mathrm{~mL}$ of the $2.1 \times 10^{-6} \mathrm{M} \mathrm{U}(\mathrm{VI})$ solution was added, and the columns eluted with $4 \mathrm{M}$ and $0.1 \mathrm{M} \mathrm{HCl}$ (flow rate of $\sim 0.63 \mathrm{~mL} /$ $\mathrm{min})$. Uranium(VI) recovery improved over the prefilled columns from $72 \%$ to $92 \%$ after 10 bed volumes of $0.1 \mathrm{M} \mathrm{HCl}$ (Figure 2, Table 2). However, the requirement for $100 \%$ recovery of micro-molar concentrations of $U$ with small elution volumes could not be achieved with this resin.

Hussonnois et al. [28] reported the use of Dowex ${ }^{\circledR}$ $1 \times 8$ resin for $\mathrm{U}(\mathrm{IV}) / \mathrm{U}(\mathrm{VI})$ separation so this resin was also selected for evaluation. Dowex ${ }^{\circledR} 1 \times 8$ powder resin was pre-washed, slurry-packed and tested in both the Poly-Prep ${ }^{\circledR}$ columns and Thermo Scientific ${ }^{\circledR}$ Pierce ${ }^{\circledR}$ polystyrene columns. The latter type of columns were packed with frits above and below the resin bed as recommended by the manufacturer making the use of a valve to stop flow unnecessary (Figure 1b). In both types of columns, $100 \%$ of the total uranium in a $1 \mathrm{~mL}$ addition of $2.1 \times 10^{-6} \mathrm{M} \mathrm{U}(\mathrm{VI})$ solution was eluted after only 3 bed volumes $(\sim 5.5 \mathrm{~mL}$ with a flow rate of $\sim 0.45 \mathrm{~mL} / \mathrm{min}$ ) of $0.1 \mathrm{M} \mathrm{HCl}$ eluent had been added (Figure 2, Table 2). Thus, complete recovery of micromolar uranium concentrations with small eluent volumes was best achieved with this resin and a total of 9 bed volumes of $0.1 \mathrm{M} \mathrm{HCl}$ eluent was chosen for the standard protocol (Table 1). A bed-height to column diameter ratio of $\sim 7$ was used in testing the Dowex $1 \times 8{ }^{\circledR}$ resin with $100 \%$ recovery (an identical ratio is inherent in the Bio-Rad ${ }^{\circledR}$ prefilled columns). However, when a larger diameter column was packed with Dowex $1 \times 8^{\circledR}$ resin with similar bed volume $(\sim 2 \mathrm{~mL})$ and a bedheight to column ratio of $\sim 3$, total recovery decreased to $95 \%$. Based on the $1 \sigma$ standard deviation, total recoveries from 25 replicate measurements with Dowex $1 \times 8^{\circledR}$ were $97-103 \%$. Consequently, the uncertainty in total recovery was assigned a value of $3 \%$. Replicate resin separations revealed highly reproducible results for each individual fraction collected with standard deviations between replicate fractions of $0.4 \%$.

\section{Recovery of $U$ under anoxic conditions - Oxidation of $U$ (IV) by resin and Ti(III) treatment}

Solutions with U(IV) were produced by adding substoichiometric amounts of anoxic $\mathrm{Ti}(\mathrm{III})$ to an anoxic $\mathrm{U}$ (VI) solution in an anaerobic chamber to produce the desired $\mathrm{U}(\mathrm{IV}) / \mathrm{U}(\mathrm{VI})$ composition. A solution $(1 \mathrm{~mL})$ with $8.7 \times 10^{-6} \mathrm{M}$ total uranium concentration containing of $98 \% \mathrm{U}(\mathrm{IV})$ and $2 \% \mathrm{U}(\mathrm{VI})$ was passed through an anoxically prepared Dowex ${ }^{\circledR} 1 \times 8$ resin-packed column. Only $86 \%$ of the uranium was recovered as U(IV); the remaining $14 \%$ was recovered as $\mathrm{U}(\mathrm{VI})$ suggesting resininduced oxidation of $\mathrm{U}(\mathrm{IV})$ (Table 2). Similar oxidation results were obtained with the Bio-Rad $\mathrm{AG}^{\circledR} 1 \times 8$ PolyPrep ${ }^{\circledR}$ prefilled columns. When $1 \mathrm{~mL}$ of a $36 \% \mathrm{U}(\mathrm{IV})$ and $64 \% \mathrm{U}(\mathrm{VI})$ solution $\left(2.1 \times 10^{-6} \mathrm{M}\right.$ total uranium concentration) was added to an anoxically prepared column, all of the recovered uranium was U(VI) (81\% total recovery). The maximum uncertainty in speciation was $1 \%$ based on duplicate recoveries of various $\mathrm{U}(\mathrm{IV}) / \mathrm{U}$ (VI) mixtures and comparison of known and experimentally determined uranium speciation $(0 / 100,36 / 64$, $98 / 2$, and $100 / 0$, described in subsequent method validation section).

The oxidative capacity of both the Dowex and Bio-Rad resins was estimated to be $\sim 0.002$ meq per liter bed volume under anoxic hydrochloric acid conditions. While this low value will not have a measureable impact on solutions with very high tetravalent uranium concentration, the oxidative capacity of a $2 \mathrm{~mL}$ bed volume resin column is sufficient to completely oxidize $1 \mathrm{~mL}$ of a $1.0 \times 10^{-6} \mathrm{M} \mathrm{U}(\mathrm{IV})$ solution (10 times the drinking water limit). Thus the implications for lower-level, field-relevant, concentrations are significant. The nature of the trace-constituent oxidant present on the resins is unknown, but the most likely oxidant is trace amounts of oxygen trapped in the resin. A dissolved oxygen concentration of $0.5 \times 10^{-6} \mathrm{M}$ could account for the observed oxidation of $\mathrm{U}(\mathrm{IV})$. Alternatively, the oxidant could be a residual from proprietary manufacturing processes. Redox reactive functional groups, such as nitro moieties, or other known oxidizers of uranium, such as nitrate or $\mathrm{Fe}(\mathrm{III})$, could be present at sufficiently low concentrations to make detection of the specific oxidant difficult.

Since the time from sample collection to KPA uranium measurement is a few days with the chloride removal step, a visual redox indicator was added to the system to assess oxidation more rapidly. Safranin-o $\left(\mathrm{C}_{20} \mathrm{H}_{19} \mathrm{ClN}_{4}\right)$ is a leuco dye redox indicator whose oxidized form is vibrant purple, red, or pink but is colorless when reduced. One drop of $1 \%$ safranin-o in the oxidized form (Thermo Fisher Scientific) was added to a $20 \mathrm{~mL}$ uranium solution $\left(8.4 \times 10^{-6} \mathrm{M}\right)$ in $4 \mathrm{M} \mathrm{HCl}$ under oxic conditions resulting in a strong purple color (Figure 1c). This solution was sparged in the glovebag to remove any dissolved oxygen and $1 \times 10^{-3} \mathrm{M} \mathrm{Ti}(\mathrm{III})$ was then added drop-wise until the solution turned colorless (Figure 1d). The solution remained colorless under anoxic conditions in the glovebag but developed a purple color, characteristic of the oxidized form, over the course of a few hours once removed from the glovebag and exposed to atmospheric conditions. Under anoxic conditions, the reduced uranium solution with indicator was added to a resinpacked column and an immediate color change to bright pink was observed on the resin (Figure 1e). All three resin types showed a color change characteristic of the oxidized form of the indicator throughout the resin bed. 
Addition of a $1 \times 10^{-3} \mathrm{M} \mathrm{Ti}(\mathrm{III})$ solution (without uranium) to the dyed resin resulted in the conversion of the indicator back to its colorless, reduced, form. Based on these results, a pre-treatment step was added to the resin packing protocol. Following pre-washing and column packing with Dowex ${ }^{\circledR} 1 \times 8$, three bed volumes of $1 \times 10^{-3} \mathrm{M} \mathrm{Ti}(\mathrm{III})$ were flushed through the resin. The column was capped at the bottom, a final 1.5 bed volume aliquot of $\mathrm{Ti}$ (III) added, the top sealed with a cap, and the system left to soak overnight. The redox
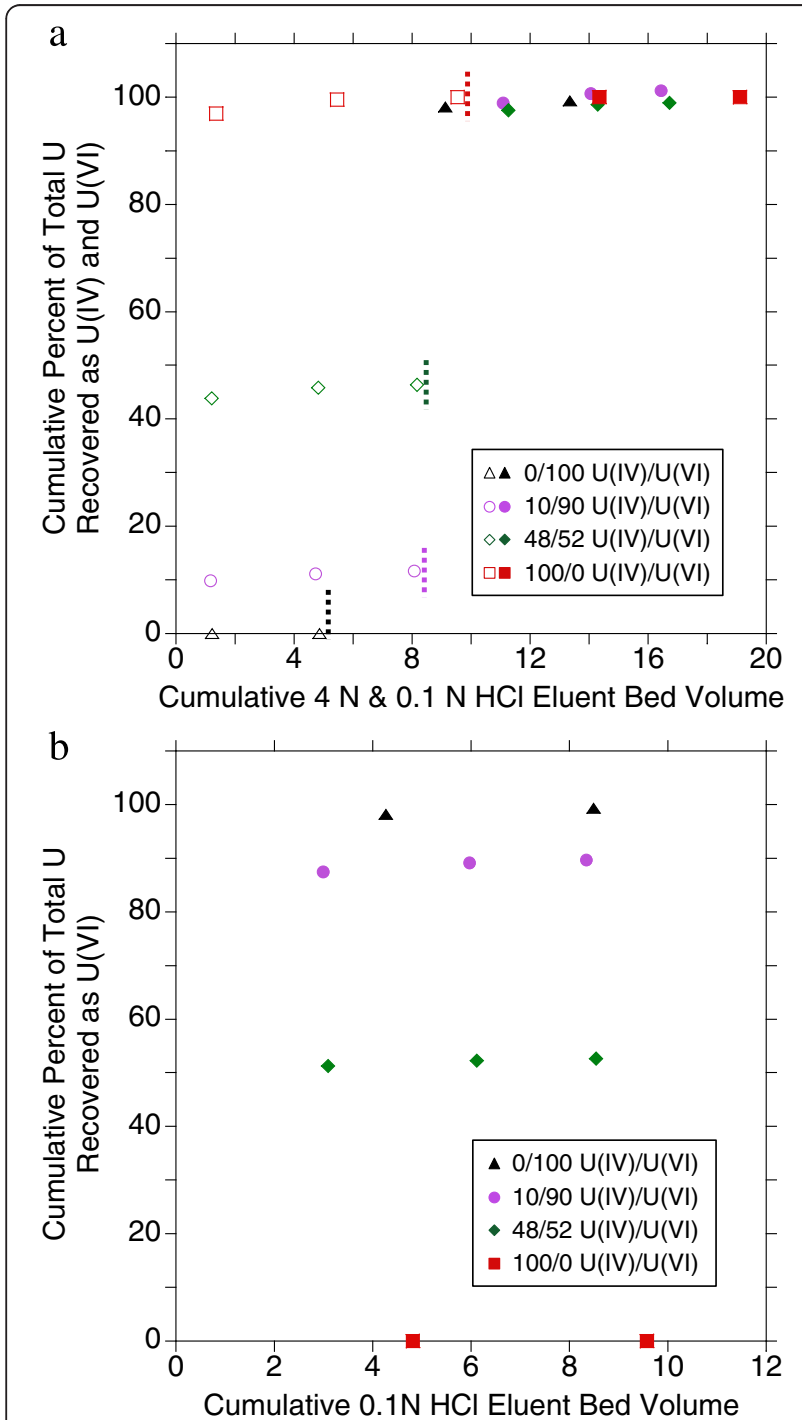

Figure $3 \mathrm{U}$ recovery from Dowex ${ }^{\circledR} 1 \times 8$ resin under anoxic conditions with varied $\mathrm{U}(\mathrm{IV}) / \mathrm{U}(\mathrm{VI})$ solutions. Dowex ${ }^{\circledR} 1 \times 8$ resin separation of anoxic solutions consisting of $0 \%, 10 \%, 48 \%$ and $100 \%$ $\mathrm{U}(\mathrm{IV})$ after resin pre-treatment showing a) cumulative recovery of total uranium for both $4 \mathrm{M} \mathrm{HCl}$ (open symbols, $\mathrm{U}(\mathrm{IV})$ ) and $0.1 \mathrm{M} \mathrm{HCl}$ (closed symbols, U(VI)) column elution with dashed lines indicating where the eluent composition was changed for each system and b) cumulative recovery of total uranium as $\mathrm{U}(\mathrm{VI})$ from only $0.1 \mathrm{M} \mathrm{HCl}$ $(\mathrm{U}(\mathrm{VI}))$ elutions. equivalents in this solution are 4 orders of magnitude greater than the amount necessary to reduce the resinbound oxidants based on the resin oxidative capacity. After the overnight equilibration, the column was flushed with $\sim 12$ bed volumes of $4 \mathrm{M} \mathrm{HCl}$ to remove any residual titanium. Fractions were collected, diluted with $0.15 \mathrm{M}$ nitric acid, and analyzed for titanium via ICP-OES (detection limit $1 \mathrm{e}^{-7} \mathrm{M}$ ). Complete recovery of titanium was achieved within 4 bed volumes of $4 \mathrm{M} \mathrm{HCl}$ eluent. To the pre-treated and flushed column, $1 \mathrm{~mL}$ of a reduced uranium solution with safranin-o indicator, in the colorless form, was added. A color change to pink was observed, indicating oxidation of some of the indicator, although it was less pronounced than it had been without $\mathrm{Ti}(\mathrm{III})$ treatment. Oxidation of $\mathrm{U}(\mathrm{IV})$ was also measured in the eluted fractions. Therefore, a more rigorous procedure was tested. A $1.0 \times 10^{-2} \mathrm{M} \mathrm{Ti}(\mathrm{III})$ solution was used in place of the $1.0 \times 10^{-3} \mathrm{M} \mathrm{Ti}$ (III) solution to pre-treat the resin. The resin was flushed with three bed volumes, after which the system was capped and allowed to soak for $\sim 3$ days prior to flushing with $4 \mathrm{M} \mathrm{HCl}$. We hypothesize that elevated $\mathrm{Ti}(\mathrm{III})$ concentrations and contact times are required to reduce all resin-bound oxidants as neither $\mathrm{Ti}(\mathrm{III})$ nor $\mathrm{Ti}(\mathrm{IV})$ sorb to the anion exchange resin in the presence of $4 \mathrm{M} \mathrm{HCl}$ [26]. Reduced indicator solutions added to resins treated in this manner remained colorless, indicating the oxidative capacity of the resin was depleted (Figure 1f). Resin pre-treatment with $1.0 \times 10^{-2} \mathrm{M}$ Ti(III) was selected for the standard protocol (Table 1).

\section{Recovery of U(IV) under anoxic conditions - Method validation}

Using the more rigorous reductive pre-treatment protocol, a series of tests was conducted on newly prepared Dowex ${ }^{\circledR} 1 \times 8$ resin columns without the addition of the leuco dye. First, a $1.8 \times 10^{-6} \mathrm{M} \mathrm{U}(\mathrm{VI})$ solution was passed through the resin and eluted with $4 \mathrm{M} \mathrm{HCl}$ and $0.1 \mathrm{M}$ $\mathrm{HCl}$ to ensure no excess reductants had been deposited on the resin. All uranium was recovered in the hexavalent form (100\% total recovery, Figure 3, Table 2). Similar to oxic $U(V I)$ tests, full recovery of $U(V I)$ under anoxic conditions was achieved within 4 bed volumes of $0.1 \mathrm{M} \mathrm{HCl}$ eluent and a total of 9 bed volumes was chosen for the standard protocol (Table 1). Next, a pure $\mathrm{U}(\mathrm{IV})$ fraction was collected by passing $1 \mathrm{~mL}$ of a $8.7 \times 10^{-6} \mathrm{M}$ total uranium concentration (98\% U(IV)) through a separately prepared resin-packed column and eluting with $2 \mathrm{~mL}$ of $4 \mathrm{M} \mathrm{HCl}$ for a final uranium concentration of $2.8 \times 10^{-6} \mathrm{M}$. This $100 \% \mathrm{U}(\mathrm{IV})$ solution was passed through a separately prepared resin-packed column. Complete U(IV) recovery was achieved after approximately 5 bed volumes of $4 \mathrm{M} \mathrm{HCl}$ elution and a total of 9 bed volumes of $4 \mathrm{M} \mathrm{HCl}$ eluent was chosen 
for the standard protocol (Table 1). Resin separation of the pure U(IV) solution showed 100\% total recovery and $100 \%$ U(IV) content (Figure 3, Table 2). To determine whether packed columns can be reused, the column used in the previous test was post-flushed with 6 additional bed volumes of $0.1 \mathrm{M} \mathrm{HCl}$ and then 6 bed volumes of $4 \mathrm{M} \mathrm{HCl}$ and the separation experiment was repeated. Results were identical with $100 \%$ total recovery and $100 \%$ as $\mathrm{U}(\mathrm{IV})$.

Four months later, the same original 98\% U(IV) solution was passed through a freshly prepared resin column with $100 \%$ total uranium recovery and $92 \%$ as U(IV). The minimal amount of U(IV) oxidation over many months suggested by these results indicates the stability of the Ti(III) reduced systems under anoxic conditions. Finally, the first fraction from the previous test, comprised of $1 \mathrm{~mL}$ of $\mathrm{U}(\mathrm{IV})$ solution and $2 \mathrm{~mL}$ of $4 \mathrm{M} \mathrm{HCl}$ eluent with a total concentration of $2.6 \times 10^{-6} \mathrm{M}$, was collected to have a pure $\mathrm{U}(\mathrm{IV})$ fraction to admix with $\mathrm{U}$ (VI). Both a $48 \% \mathrm{U}(\mathrm{IV}) / 52 \% \mathrm{U}(\mathrm{VI})$ and a $10 \% \mathrm{U}(\mathrm{IV})$ / $90 \% \mathrm{U}(\mathrm{VI})$ solution were prepared by mixing an aliquot of the pure U(IV) fraction with an aliquot of anoxic $U$ (VI) solution for final total uranium concentrations of $2.1 \times 10^{-6} \mathrm{M}$ and $1.8 \times 10^{-6} \mathrm{M}$ respectively. When these solutions were passed through pre-washed, pre-treated resins and eluted the total uranium recovery was $100 \%$ for each test with measured U(IV)/U(IV) ratios of 47/53 and 11/89 respectively (Figure 3 and Table 2).

\section{Summary and conclusions}

In choosing the proper strong base anion exchange resin for separation of redox sensitive species, careful consideration should be paid not only to the efficiency of recovery of each constituent but also the potential for resin-induced oxidation. Three different resins (two from the same manufacturer) with identical mesh size, base form, and exchange capacity were found to sorbed $\mathrm{U}(\mathrm{VI})$ very strongly in $4 \mathrm{M} \mathrm{HCl}$ but recoveries of $\mathrm{U}(\mathrm{VI})$, from elution with $0.1 \mathrm{M} \mathrm{HCl}$, varied between $72 \%$ and $100 \%$. In addition, all three resins were found to cause oxidation of U(IV) under anoxic conditions in a glovebag. Oxidative properties were observed by measuring $\mathrm{U}$ (IV) and U(VI) but also by the addition of a leuco dye to the resin, which allowed an immediate visual indication of redox transformations. The use of visual redox indicators, when possible, can offer significant time savings in method development and testing when sample analysis is a lengthy process. The oxidative capacity of these anion exchange resins was eliminated by treatment with the reducing agent $\mathrm{Ti}(\mathrm{III})$. To achieve $\mathrm{U}(\mathrm{IV}) / \mathrm{U}(\mathrm{VI})$ separation, soaking resin-packed columns in a solution of $1 \times 10^{-2} \mathrm{M}$ Ti(III) permanently removed the residual oxidants present on the resin. $\mathrm{Ti}(\mathrm{III})$ was completely flushed from the column and did not further impact results (e.g. reduction of $\mathrm{U}(\mathrm{VI})$ or instrumental interferences) with future resin use. After pre-treatment, U(IV)/ $\mathrm{U}(\mathrm{VI})$ resin separation was found to be accurate, reproducible and packed resin columns reusable after postseparation flushing. Future work utilizing this treatment technique will be applied to field-collected anoxic sediments for the characterization of associated U(IV) and $\mathrm{U}(\mathrm{VI})$.

\section{Competing interests}

The authors declare that they have no competing interests.

\section{Authors' contributions}

DLS designed and conducted the experiments, prepared/analyzed KPA and ICP samples, interpreted the data, and wrote this manuscript. NK performed the resin prewashing and pretreatment steps, prepared/analyzed KPA samples, conducted the leuco-dye tests and two untreated anoxic resin separations included here along with many additional tests which are not included but significantly impacted the final experimental design. DBK and JAD helped revise this manuscript and offered experimental design suggestions. All authors read and approved the final manuscript.

\section{Acknowledgements}

Funding for this work was provided by the U.S. Department of Energy (DOE), Office of Science, Subsurface Biogeochemical Research through the Rifle Integrated Field Research Challenge. Additional funding was provided by the U.S. Geological Survey National Water Quality Assessment, Toxic Substances Hydrology, and Hydraulic Research and Development Programs. The authors thank Patricia Fox, Chris Fuller, and Matthias Kohler for profitable discussions and laboratory assistance. These contributions, along with reviews by Matthias Kohler and two anonymous reviewers, greatly improved this manuscript. Use of trade names is for identification purposes only and does not constitute endorsement by the USGS, DOE, or other U.S. Government entities.

\section{Author details}

${ }^{1}$ U.S. Geological Survey, 345 Middlefield Rd, Menlo Park, CA 94025, USA. 'Lawrence Berkeley National Laboratory, 1 Cyclotron Rd, Berkeley, CA 94720, USA.

Received: 27 August 2012 Accepted: 27 January 2013

Published: 31 January 2013

\section{References}

1. Ayotte JD, Baris D, Cantor KP, Colt J, Robinson GR Jr, Lubin JH, Karagas M, Hoover RN, Fraumeni JF Jr, Silverman DT: Bladder cancer mortality and private well use in New England: An ecological study. J Epidemiol Commun H 2006, 60:168-172.

2. Thiros SA: Conceptual understanding and groundwater quality of the basin-fill aquifer in the Central Valley, California. In Conceptual understanding and groundwater quality of selected basin-fill aquifers in the southwestern United States, U.S. Geological Survey Professional Paper 1781. Edited by Thiros SA, Bexfield LM, Anning DW, Huntington JM. Reston, VA: U. S. Geological Survey; 2010:267-287.

3. Anderson RT, Vrionis HA, Ortiz-Bernad I, Resch CT, Long PE, Dayvault R, Karp K, Marutzky S, Metzler DR, Peacock A, White DC, Lowe M, Lovley DR: Stimulating the in situ activity of Geobacter species to remove uranium from the groundwater of a uranium-contaminated aquifer. Appl Environ Microbiol 2003, 69:5884-5891.

4. Curtis GP, Davis JA, Naftz DL: Simulation of reactive transport of uranium (VI) in groundwater with variable chemical conditions. Water Resour Res 2006, 42:W04404. doi:10.1029/2005WR003979.

5. Yabusaki S, Fang Y, Waichler SR: Building conceptual models of field-scale uranium reactive transport in a dynamic vadose zone-aquifer-river system. Water Resour Res 2008, 44:W12403. doi:10.1029/2007WR006617.

6. Ginder-Vogel M, Stewart B, Fendorf S: Kinetic and mechanistic constraints on the oxidation of biogenic uraninite by ferrihydrite. Environ Sci Technol 2010, 44:163-169. 
7. Lovely D, Phillips EJP, Gorby Y, Landa ER: Microbial reduction of uranium. Nature 1991, 350:413-416.

8. O'Loughlin EJ, Kelly SD, Cook RE, Csencsits R, Kemner KM: Reduction of uranium (VI) by mixed iron(II)/iron(III) hydroxide (green rust): Formation of $\mathrm{UO}_{2}$ nanoparticles. Environ Sci Technol 2003, 37:721-727.

9. Jeon BH, Dempsey BA, Burgos WD, Barnett MO, Roden E: Chemical reduction of $\mathrm{U}(\mathrm{VI})$ by $\mathrm{Fe}(\mathrm{II})$ at the solid - water interface using natural and synthetic Fe(III) oxides. Environ Sci Technol 2005, 39:5642-5649.

10. Wu W-M, Carley J, Luo J, Ginder-Vogel MA, Cardenas E, Leigh MB, Hwang C, Kelly SD, Ruan C, Wu L, Van Nostrand J, Gentry T, Lowe K, Mehlhorn T, Carroll S, Luo W, Fields MW, Gu B, Watson D, Kemner KM, Marsh T, Tiedje J, Zhou J, Fendorf S, Kitanidis PK, Jardine PM, Criddle CS: In situ bioreduction of uranium (VI) to submicromolar levels and reoxidation by dissolved oxygen. Environ Sci Technol 2007, 41:5716-5723.

11. Yabusaki SB, Fang Y, Long PE, Resch CT, Peacock AD, Komlos J, Jaffe PR, Morrison SJ, Dayvault RD, White DC, Anderson RT: Uranium removal from groundwater via in situ biostimulation: Field-scale modeling of transport and biological processes. J Contam Hydrol 2007, 93:216-235.

12. Burgos WD, McDonough JT, Senko JM, Zhang GX, Dohnalkova AC, Kelly SD, Gorby Y, Kemner KM: Characterization of uraninite nanoparticles produced by Shewanella oneidensis MR-1. Geochim Cosmochim Acto 2008, 72:4901-4915.

13. Sheng L, Szymanowksi J, Fein JB: The effects of uranium speciation on the rate of $\mathrm{U}(\mathrm{VI})$ reduction by Shewanella oneidensis MR-1. Geochim Cosmochim Acta 2011, 75:3558-3567.

14. Fletcher KE, Boyanov MI, Thomas SH, Wu QZ, Kemner KM, Löffler FE: U(VI) Reduction to mononuclear U(IV) by desulfitobacterium species. Environ Sci Technol 2010, 44:4705-4709.

15. Bernier-Latmani R, Veeramani $H$, Dalla Vecchia E, Junier $P$, Lezama-Pacheco JS, Suvorova El, Sharp JO, Wigginton NS, Bargar JR: Non-uraninite products of microbial U(VI) reduction. Environ Sci Technol 2010, 44:9456-9462.

16. Boyanov MI, Fletcher KE, Kwon MJ, Rui X, O'Loughlin EJ, Löffler FE, Kemner KM: Solution and microbial controls on the formation of reduced U(IV) species. Environ Sci Technol 2011, 45:8336-8344.

17. Campbell KM, Davis JA, Bargar J, Giammar D, Bernier-Latmani R, Kukkadapu R, Williams KH, Veeramani H, Ulrich K-U, Stubbs J, Yabusaki S, Fiqueroa L, Lesher E, Wilkins MJ, Peacock A, Long PE: Composition, stability, and measurement of reduced uranium phases for groundwater bioremediation at Old Rifle, CO. Appl Geochem 2011, 26:S167-S169.

18. Ray AE, Bargar JR, Sivaswamy V, Dohnalkova A, Fujita Y, Peyton BM, Magnuson TS: Evidence for multiple modes of uranium immobilization by an anaerobic bacterium. Geochim Cosmochim Acta 2011, 75:2684-2695.

19. Sharp JO, Lezama-Pacheco JS, Schofield EJ, Junier P, Ulrich K-U, Chinni S, Veeramani H, Margot-Roquier C, Webb SM, Tebo BM, Giammar DE, Bargar $J R$, Bernier-Latmani R: Uranium speciation and stability after reductive immobilization in aquifer sediments. Geochim Cosmochim Acta 2011, 75:6497-6510.

20. Veeramani H, Alessi DS, Suvorova El, Lezama-Pacheco JS, Stubbs JE, Sharp JO, Dippon U, Kappler A, Bargar JR, Bernier-Latmani R: Products of abiotic $\mathrm{U}(\mathrm{VI})$ reduction by biogenic magnetite and vivianite. Geochim Cosmochim Acta 2011, 75:2512-2528.

21. Alessi DA, Uster B, Veeramani H, Suvorova El, Lezama JA, Stubbs JE, Bargar J, Bernier-Latmani R: Quantitative separation of monomeric U(IV) from $\mathrm{UO}_{2}$ in products of $\mathrm{U}(\mathrm{VI})$ reduction. Environ Sci Technol 2012, 46:6150-6157.

22. Campbell KM, Kukkadapu RK, Qafoku N, Peacock AD, Lesher E, Williams KH, Bargar JR, Wilkins MJ, Figueroa LA, Ranville J, Davis J, Long PE: Geochemical, mineralogical and microbiological characteristics of sediment from a naturally reduced zone in a uranium-contaminated aquifer. App Geochem 2012, 27:1499-1511.

23. Kaminski R, Purcell FJ, Russavage E: Uranyl phosphorescence at the partsper-trillion level. Anal Chem 1981, 53:1093-1096.

24. Brina R, Miller AG: Direct detection of trace levels of uranium by laserinduced kinetics phosphorimetry. Anal Chem 1992, 64:1413-1418.

25. Kraus K, Moore GE, Nelson F: Anion-exchange studies. XXI. Th(IV) and U (IV) in hydrochloric acid. Separation of thorium, protactinium and uranium. J Am Chem Soc 1956, 78:2693-2694.

26. Gindler JE: The radiochemistry of uranium. Springfield, VA: Subcommittee on Radiochemistry, National Academy of Sciences, National Research Council; 1962.
27. Cochran JK, Carey AE, Sholkovitz ER, Surprenant DL: The geochemistry of uranium and thorium in coastal marine sediments and sediment pore waters. Geochim Cosmochim Acta 1986, 50:663-680.

28. Hussonnois M, Guillaumont R, Brillard L, Fattahi M: A method for determining the oxidation state of uranium at concentration as low as $10^{-10} \mathrm{M}$. In Material Research Society Proceeding Vol 127. Edited by Lutze W, Ewing RC. New York: Cambridge University Presss; 1989:979-985.

29. Skogley EO, Dobermann A: Synthetic ion-exchange resins: soil and environmental studies. J Environ Qual 1996, 25:13-24.

30. Gu B, Ku Y-K, Brown GM: Sorption and desorption of perchlorate and U (VI) by strong-base anion-exchange resins. Environ Sci Technol 2005, 39:901-907.

31. Gu B, Ku Y-K, Jardine PM: Sorption and binary exchange of nitrate, sulfate, and uranium on an anion-exchange resin. Environ Sci Technol 2004, 38:3184-3188.

32. Phillips DH, Gu B, Watson DB, Parmele CS: Uranium removal from contaminated groundwater by synthetic resins. Water Res 2008, 42:260-268.

33. Stucker V, Ranville K, Newmann M, Peacock A, Cho J, Hatfield K: Evaluation and application of anion exchange resins to measure groundwater uranium flux at a former uranium mill site. Water Res 2011, 45:4866-4876.

doi:10.1186/1467-4866-14-1

Cite this article as: Stoliker et al.: Evaluating ion exchange resin efficiency and oxidative capacity for the separation of uranium(IV) and uranium(VI). Geochemical Transactions 2013 14:1.

\section{Submit your next manuscript to BioMed Central and take full advantage of:}

- Convenient online submission

- Thorough peer review

- No space constraints or color figure charges

- Immediate publication on acceptance

- Inclusion in PubMed, CAS, Scopus and Google Scholar

- Research which is freely available for redistribution

Submit your manuscript at www.biomedcentral.com/submit
C Biomed Central 